\title{
エアロゾルデポジションを活用した酸化物全固体電池の研究開発
}

\author{
山本 貴之, 本山 宗主, 入山 恭寿* \\ 名古屋大学工学研究科材料デザイン工学専攻, $\bar{\top}$ 464-8603 名古屋市千種区不老町.
}

\section{Oxide-based All-Solid-State Batteries Using Aerosol Deposition}

\author{
Takayuki YAMAMOTO, Munekazu MOTOYAMA and Yasutoshi IRIYAMA* \\ Department of Materials Design Innovation Engineering, Graduate school of Engineering, Nagoya University, \\ Furo-cho, Chikusa-ku, Nagoya 464-8603, Japan.
}

Received November 5, 2019; Revised December 21, 2019; Accepted December 24, 2019

\begin{abstract}
Oxide-based all-solid-state batteries (OX-SSBs) have been expected as next generation rechargeable batteries. In the OX-SSBs, charge transfer reaction occurs at electrode-solid electrolyte interface and then both of them must adhere well with smaller interfacial ion transfer resistance. Although various kinds of electrodes and solid electrolytes have been proposed, most of them are composed of different elements and concentrations, and, in addition, they have different thermal stability. Thus, sintering process frequently provide mutual diffusion layer around the interface, which often induce highly resistive interface and then degrade the performance of the OXSSBs. To overcome this problem, we have focused on aerosol deposition (AD), a room temperature ceramics densification technology, to develop electrode-solid electrolyte interface at lower temperature. By applying the $\mathrm{AD}$ process, we have developed $4 \mathrm{~V}$ - and $5 \mathrm{~V}$-class electrode-solid electrolyte composite electrodes and investigated their electrochemical properties as $\mathrm{OX}-\mathrm{SSBs}$ at $100^{\circ} \mathrm{C}$. Moreover, the $\mathrm{AD}$ can realize inverted-stack $\mathrm{Li}$-free thin-film OX-SSBs, where crystalline $\mathrm{LiCoO}_{2}$ electrode is formed on amorphous LiPON film. Our recent works on OX-SSBs using the AD will be introduced in this review.
\end{abstract}

\section{KEY WORDS}

aerosol deposition, all-solid-state battery, interface

\section{1 緒言}

リチウムイオン電池を凌駕する高エネルギー密度をもつ次 世代電池の研究開発が活発に進められており ${ }^{1)}$, 酸化物全固 体リチウム二次電池はその候補の一つである。酸化物全固体 リチウム二次電池の模式図を Fig. 1 に示す. リチウムイオン 電池では有機電解液が用いられるが, 酸化物全固体リチウ 厶二次電池では $\mathrm{Li}^{+}$伝導性の酸化物系固体電解質が用いられ る.ここでは, 正極に $\mathrm{LiCoO}_{2}(\mathrm{LCO})$ ，負極に $\mathrm{Li}$ 金属を用い た場合を想定しているが, 正極側ではリチウムイオン $\left(\mathrm{Li}^{+}\right)$ の挿入脱離反応が, 負極側では $\mathrm{Li}$ 金属の析出溶解反応が起 こる. 電池のエネルギー密度の指標の一つとして Wh/kg（重 量エネルギー密度）が用いられるが， $\mathrm{Wh} / \mathrm{kg}=\mathrm{V} \times \mathrm{Ah} / \mathrm{kg}$ で あることを考えると, 極めて単純には電池の作動電圧 $(\mathrm{V})$ の向上, 電極容量 $(\mathrm{Ah} / \mathrm{kg})$ の高い材料の利用がエネルギー

\footnotetext{
* Corresponding author, E-mail: iriyama@numse.nagoya-u.ac.jp
}

密度の増大に有用である。酸化物系固体電解質は一般に耐酸 化性に優れ，これは“V”の向上に有利である。また，固体 電解質がデンドライト成長を防止する隔壁として機能する ため, 高容量負極材料である $\mathrm{Li}$ 金属（３860 Ah/kg: $\mathrm{Li}^{+}+\mathrm{e}^{-}$ $=\mathrm{Li}$ の反応から算出）を利用することも可能と考えられ，こ れは“Ah/kg”の向上に有利である. 更に,

- 安全性の向上（有機電解液は可燃性, 固体電解質は不燃性) - 長寿命化（副反応（電極の溶出, 電解液の分解等）の防止） ・液漏れの解消（電池の簡素化） など, 電池の高エネルギー密度化に加えて安全性・寿命・信 頼性の向上等も期待できる. 小型の酸化物全固体リチウム二 次電池は薄膜電池として既に実用化されており, 数万回の充 放電が可能である ${ }^{2)}$. それら電池の電極活物質は一般にミク ロンオーダーの薄膜であり，スパッタリング法などの真空技 術を用いて作製される ${ }^{2-3)}$. こうした薄膜電池は, IoTの分野 等での活用が期待される。一方, 車載用などの大型デバイス 


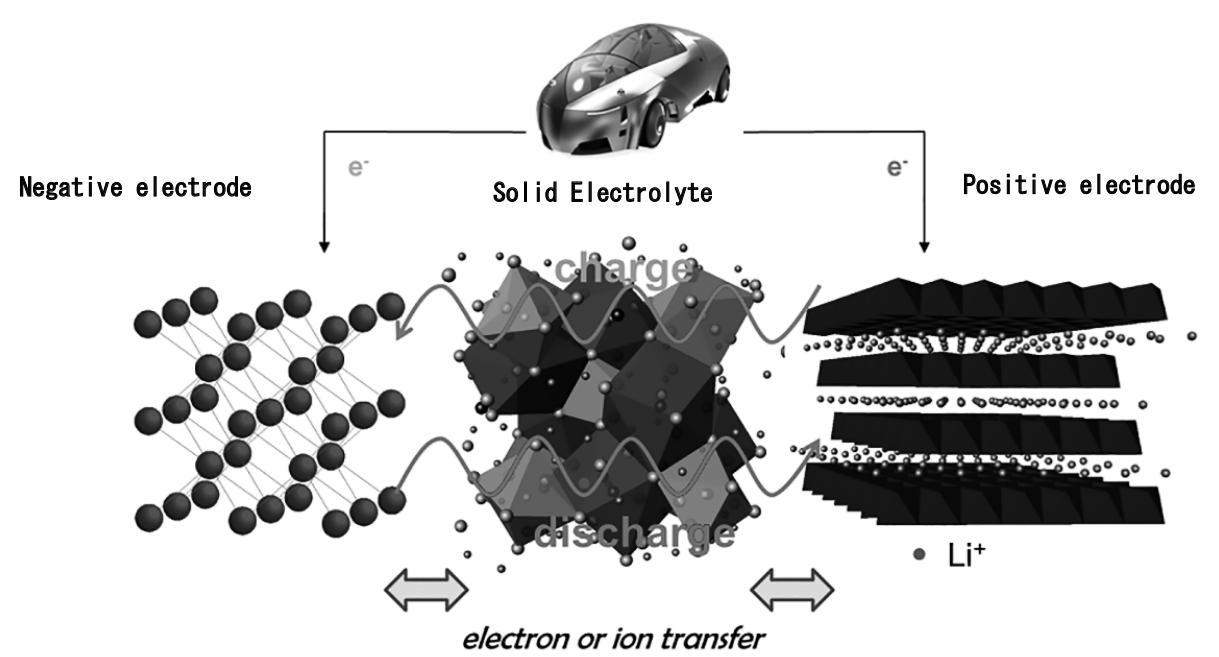

Positive electrode $\quad: \mathrm{LiCoO}_{2} \rightleftarrows \mathrm{Li}_{(1-\mathrm{x})} \mathrm{CoO}_{2}+\mathrm{xLi}^{+}+\mathrm{xe}^{-}$

Negative electrode : $\mathrm{Li} \quad \rightleftarrows \mathrm{Li}^{+}+\mathrm{e}^{-}$

Fig. 1 Schematic image of all-solid-state battery.

の電源としても酸化物全固体リチウム二次電池は期待されて いるが，その場合には数十 $\mu \mathrm{m}$ 厚みの電極 - 固体電解質複合 体を広範囲に構築する必要がある。無論, その複合体は高電 流密度で充放電可能となるように低抵抗である必要がある.

酸化物全固体リチウム二次電池の性能を左右する一つの因 子は, 電極 - 固体電解質の接合である. 酸化物系固体電解質 は硬くて脆い材料であり，正極も一般にはLCO 等のリチウ 么含有遷移金属酸化物である。そのため, 両物質の粉末を混 合・プレスするのみでは点接触となり界面でイオンが移動す る面積を十分にかせげない，一方，焼結すれば両者を接合す ることは可能であるが，相互拡散に起因した高抵抗な反応相 が形成されやすい.これらは共に界面での $\mathrm{Li}^{+}$移動を阻害し, 電池の出入力特性を低減させる要因となる。 そこで注目され るプロセスの一つが, 常温で緻密なセラミックス膜を作製で きるエアロゾルデポジション（AD）法である ${ }^{4)}$. 本報では, $\mathrm{AD}$ 法を用いて電極 - 固体電解質の常温接合膜を作製し, こ れを用いた酸化物全固体リチウム二次電池の開発事例につい て述べる.

\section{AD 法について}

Fig. 2 に AD 装置の概略を示す. $\mathrm{AD}$ 法では薄膜化したい材 料の粉末を原料に用いる. 粉末を入れるポットは真空排気さ れたチャンバーとノズルを介してつなげられている．ポット にガスを導入するとエアロゾルが生成し，これがノズルを介 してチャンバーにセットされた基板に吹き付けられる。この 際，基板は一般に加熱されず，左右に動かすことでセラミッ ク膜が広範囲に成膜される.

$\mathrm{AD}$ 法で緻密なセラミック膜が形成される原理について は様々な要因が提案されているが4), 粉末が衝突した際の破 砕・変形等を伴う新生面の露出 ${ }^{5)}$, 带電した粉末の破砕に伴 う局所的なスパッタリング-7) 等により表面活性化が生じ, 接合による表面エネルギーの低下が常温接合の駆動力の一つ

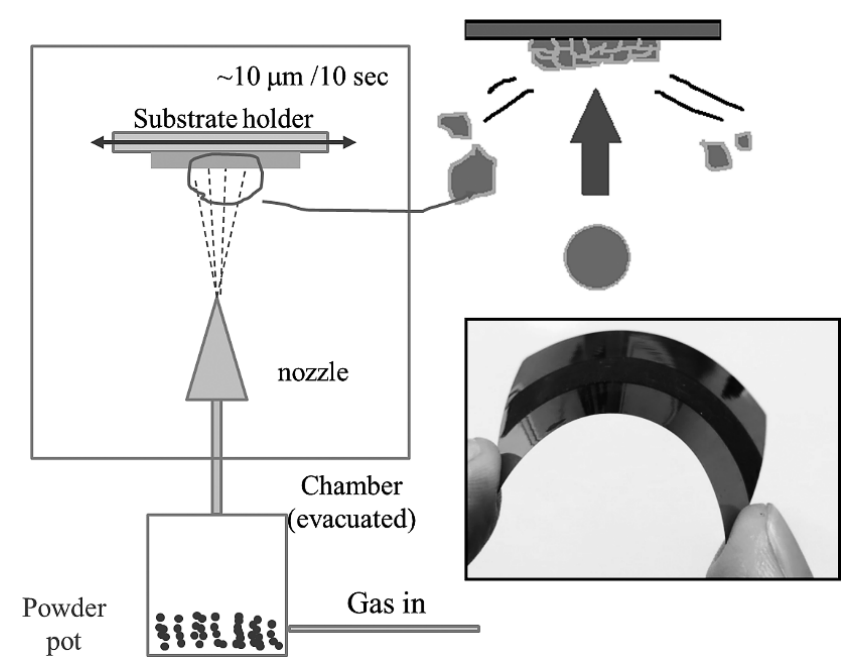

Fig. 2 Schematic image of AD apparatus. The inset picture is optical image of electrode-solid electrolyte composite film prepared by AD.

になっていると考えられる，粉末が高速に基板に吹き付けら れることで圧力が加わり, これが膜の緻密化に一部寄与して いると推察される. 一方, 常温プロセスであるため化学的な 反応の自由エネルギー変化の緻密化への寄与は通常の焼結よ り抑えられると考えられる。前述の様に酸化物全固体電池の 電極一固体電解質界面では一般的な焼結温度よりかなり低い 温度で反応する事例が多いため, 化学的な反応の自由エネル ギー変化の寄与を抑えて緻密化できる $\mathrm{AD}$ 法は酸化物全固体 電池の研究開発に有用だと考えられる.

\section{3 複合膜作製における出発粒子の影響について} 3.1 混合方法の影響

Fig. 3 は, 電極活物質である $\mathrm{LiNi}_{1 / 3} \mathrm{Co}_{1 / 3} \mathrm{Mn}_{1 / 3} \mathrm{O}_{2}(\mathrm{NCM}$ : 日 本化学社製：平均粒径 $10 \mu \mathrm{m} ）$ と固体電解質である Li-Al-TiP-O 系結晶化ガラス (LATP : オハラ社製：平均粒径 $0.5 \mu \mathrm{m}$ ) 


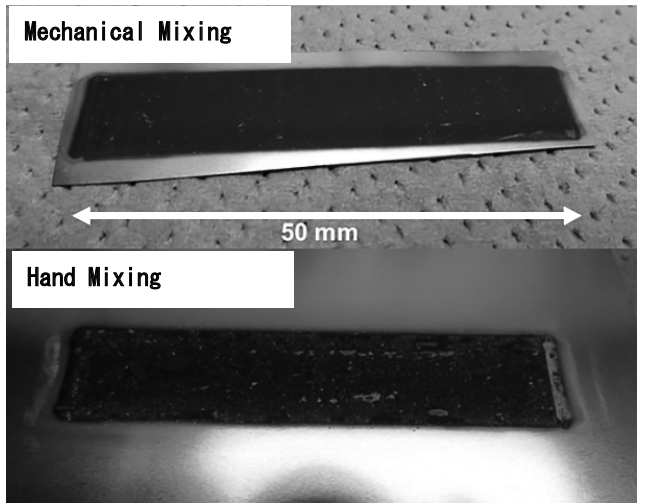

Fig. 3 Optical images of the AD films prepared on SUS substrate, where the starting powders were prepared by mechanical mixing process and hand mixing.

の複合膜を構築する際に，機械混合（ホソカワミクロン社 製：ノビルタ）により固体電解質粒子を電極粒子上に被覆し た粒子を用いた場合と，メノウ乳鉢で手混合した粒子を用い て SUS 基板上に AD 成膜した試料の光学写真である．機械 混合した粒子を用いると剥離やムラが目視では確認できない 複合膜が得られるが，手混合した粒子を用いると部分的に剥 離が認められ, 膜の濃淡が目視でも確認される。このように, できるだけ均一な複合膜を構築する上では出発粒子をあらか じめよく複合化した粒子を用いることが重要である.

3.2 表面被覆の影響8)

上述した NCM 粒子表面上に転動流動コーティング装 置（パウレック社製）を用いてアモルファスの Nb-O を 10$40 \mathrm{~nm}$ 被覆した粒子を作製した。以後, $\mathrm{Nb}-\mathrm{O}$ を $x \mathrm{~nm}$ 被覆し た粒子を「Nb-x 粒子」と表記する．Fig. 4 に示すように被覆 した $\mathrm{Nb}$ が $\mathrm{NCM}$ 粒子表面にほほ均一に被覆している様子が わかる.

これらの粒子を用いて $\mathrm{Si}$ 基板上に作製した複合膜の断面 SEM 像を Fig. 5 に示す. Nb-0 粒子（すなわち Nb-O を被覆し ていない NCM 粒子）を用いた場合， $\mathrm{Si}$ 基板上に薄膜は堆積 しなかった。一方, Nb-10, Nb-20, Nb-30, Nb-40の各粒子
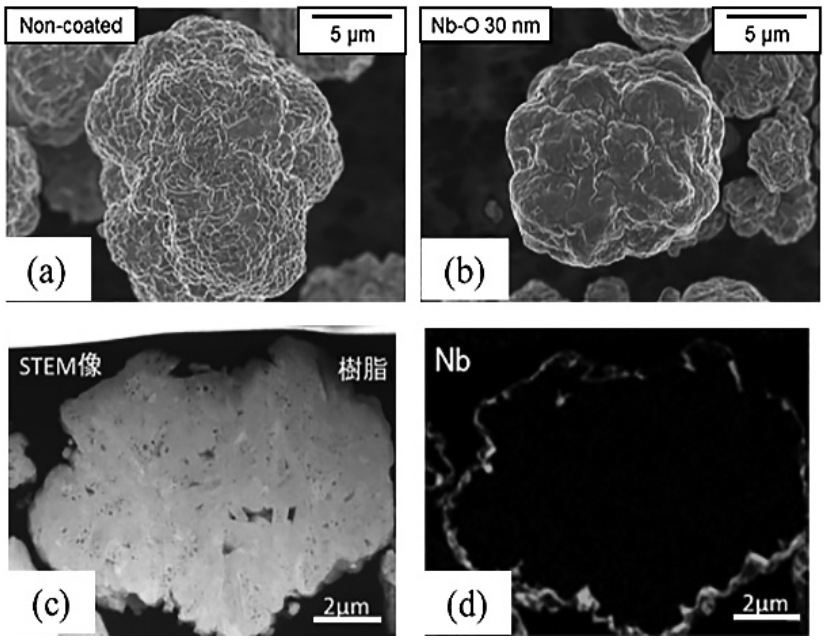

Fig. 4 SEM images of (a) NCM mother powder, (b) Nb-30, (c) Nb-30 (cross section), (d) EDX profile of Nb in Fig. 4 (c).

を用いると，同じ粒子径でも成膜が起こるようになる，これ は, $\mathrm{NbO}$ 被覆で粒子の帯電状態が変わり，破砕の際に局所 的なスパッタリングが生じることで表面活性が向上したこと で成膜効率が増大したためと考えられる。ナノオーダーの表 面被覆で成膜効率を改善できることを示している.

3.3 粉末形状の影響

複合膜内部の固体電解質の体積分率を $\varepsilon$, 固体電解質の真 の $\mathrm{Li}^{+}$伝導率を $\sigma$, 厚み方向に対する固体電解質の屈曲度を $\rho$ とすると, 複合膜内部の有効イオン伝導率 $\left(\sigma_{\mathrm{eff}}\right)$ は

$$
\sigma_{\text {eff }}=(\varepsilon / \rho) \times \sigma
$$

と表される. $\varepsilon$ が同じであれば，電極－固体電解質の複合膜 内部の $\sigma_{\text {eff }}$ 向上するためには $\rho$ が出来るだけ小さく, その 分布幅を小さくすることは反応の均一性を向上する上で有用 である，そのような複合組織を構築するためには，固体電解 質は基板に対して水平に分布させるのではなく，出来るだけ 垂直方向に分布させる必要がある。この際, 出発粒子の形状 が複合組織に影響を及ぼす一因となる。

偏平形状の LCO 粒子（日本化学社製）と形状加工して作
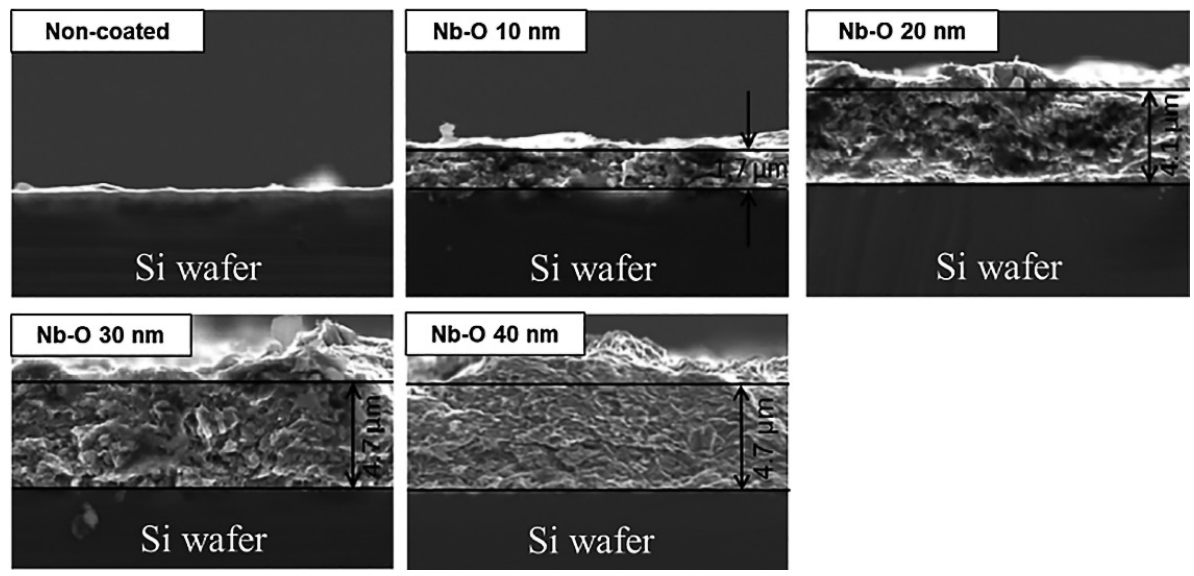

Fig. 5 Cross sectional SEM images of AD films prepared on Si substrates using $\mathrm{Nb}-x$ particles. 
(a)
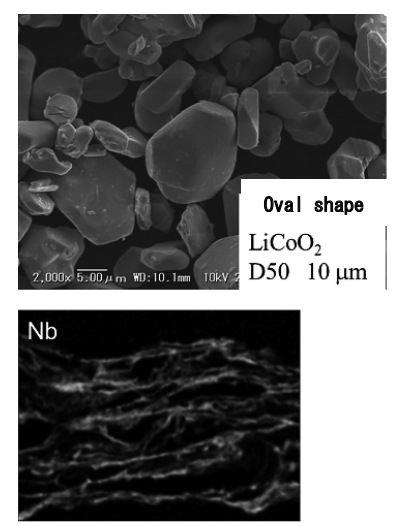

Fig. 6 EDX profile of Nb in LCO-NbO composite film, where (a) ovalshaped or (b) round-shaped particles were used.

製した球状 LCO 粒子の表面にアモルファス Nb-O を被覆し た粒子を用いて作製した複合膜中の $\mathrm{Nb}$ の断面 EDXを Fig. 6 に示す．偏平 $\mathrm{LCO}$ 粒子を用いると, $\mathrm{Nb}$ が基板に対して水平 に分布している様子がわかる．複合膜内部において $\mathrm{Nb}$ 領域 を $\mathrm{Li}^{+}$が移動する状況を考えると, $\mathrm{Li}^{+}$は膜厚方向に迂回しな がら移動しなければならない。これは $\rho$ を増大させ， $\sigma_{\mathrm{eff}}$ を 減少させる要因となる。, 一方, 球状 LCO を用いると, この 水平方向への分布が緩和されている様子がわかる。この結果 は, 出発粒子の形状が複合膜組織に影響を及ぼすことを示し ている.

\section{AD 法を活用した酸化物全固体リチウム電池の開発}

$4.14 \mathrm{~V}$ 級酸化物全固体リチウム電池の開発 ${ }^{9}$

$\mathrm{NCM}$ 粒子 (平均粒径 : $10 \mu \mathrm{m}$ ) の上にLATP（平均粒径： $0.5 \mu \mathrm{m})$ を機械混合で分散した。この際, 混合するLATPの 含有量（重量％）を $0,2 ， 5 ， 10 ， 20 \%$ に変えた。以後は，
これら粒子をLTP-0,2,5,10,20 と表記する。作製された複合粒 子の SEM 像を Fig. 7 (left) に示す。母粒子である NCM の周 りに，子粒子であるLATPが付着している。この被覆率を画 像解析ソフトを用いて計算した結果を Fig. 7 (right) に示す.

LATPの含有量が $5 \%$ の時に被覆率が最大值（～70\%）を示 し，これょり多くのLATPを複合化しても被覆率は一定と なった. SEM像を見ると, LTP-10, LTP-20ではNCMに付 着していない脱落した LATP 粒子が認められる.

これら粒子を用いて Si 基板上に成膜した NCM-LATP 複合 膜の断面 SEM 像を Fig. 8 (left) に示す。また, Fig. 8 (right) に は作製した薄膜の厚み（○）と膜内の NCM 含有量（体積\% $(\bigcirc)$, 重量 \% $(\triangle))$ の関係をまとめて示す. NCM 粒子単 独ではほとんど成膜されないのは, $\mathrm{AD}$ 成膜に本来適した粒 径ではないことに起因していると考えられる。一方, LATP と複合化した粒子を用いると成膜が認められるようになる のは, 3.2 で述べた表面被覆による影響と考えられる. LATP の含有量が増大すると, 複合膜の厚みは増大し, 一方で複合 膜内部の NCM 含有量は減少する傾向がある.また, Fig. 8 (right)のグラフ中の数值は, SEM から求めた膜厚をもとに算 出した見かけの密度であるが, LTP-5 までは 100\%に近い密 度が得られているのに対し, LTP-10 以降になると密度が減少 する傾向が認められている. LATP 単独で成膜すると圧粉体 が構築されることを考えると, LTP-10 以降で密度が低下す るのは, 脱落したLATP 粒子の成膜に起因すると推察される.

以上の検討から, 密度が高く比較的厚い膜が形成できる LTP-5 を用いて, 酸化物全固体リチウム電池の開発を進めた. Fig. 9 (a)には $\mathrm{Li}_{7} \mathrm{La}_{3} \mathrm{Zr}_{2} \mathrm{O}_{12}$ （LLZ：豊島製作所製）の緻密なぺ レットの片面にLTP-5 を用いて NCM-LATP 複合電極を成膜 した試料の断面 SEM 像を示す. AD 成膜する際の LTP-5 の粉 体量を増やすことで $20 \mu \mathrm{m}$ 程度の厚みの複合膜が LLZ 基板 上に成膜できる. LLZ は Li 金属に対しても安定な固体電解
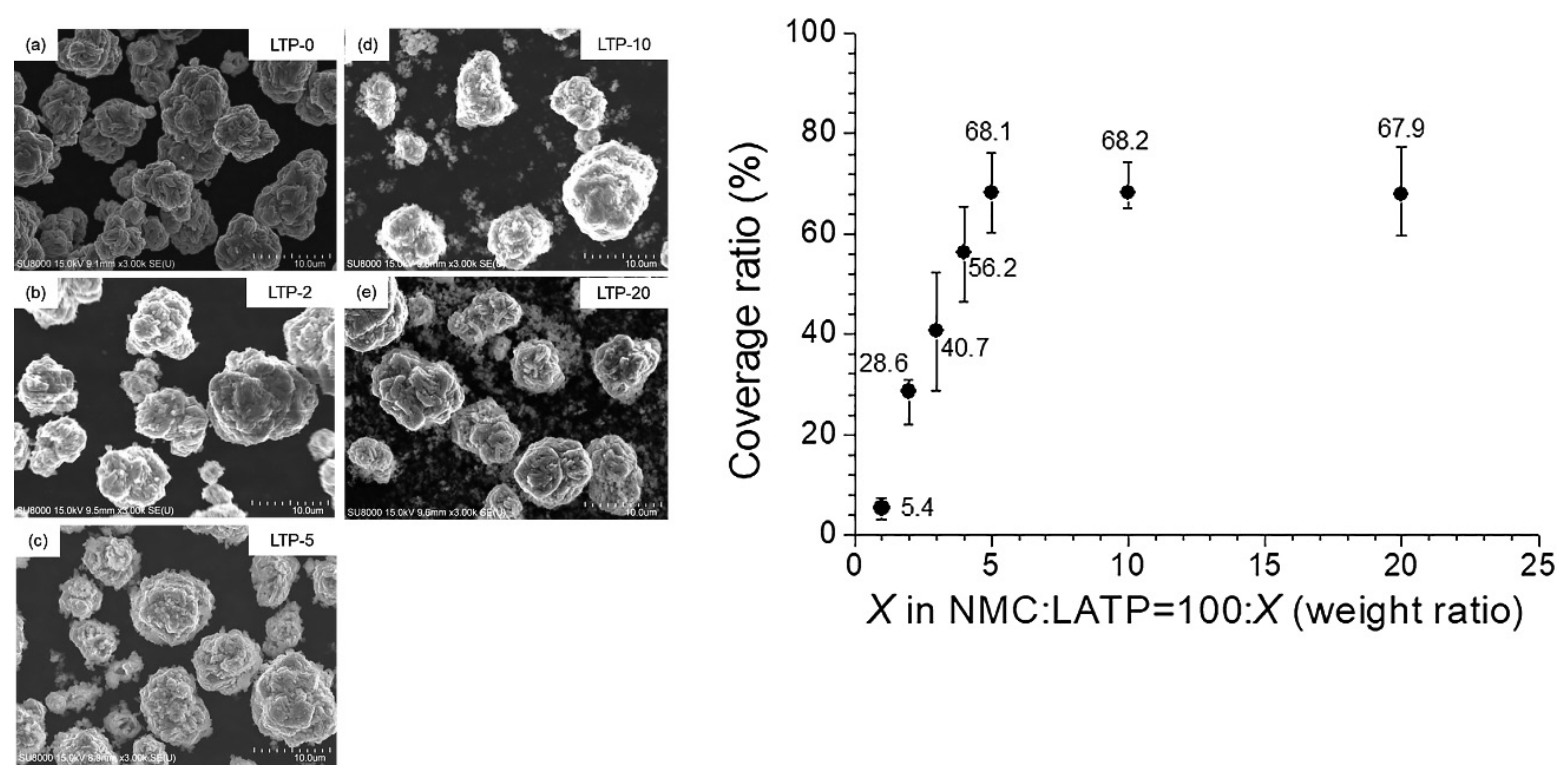

Fig. 7 (left) SEM images of LTP-0, 2, 5, 10, and 20. (right) Coverage ratio changes with the amount of LATP. 

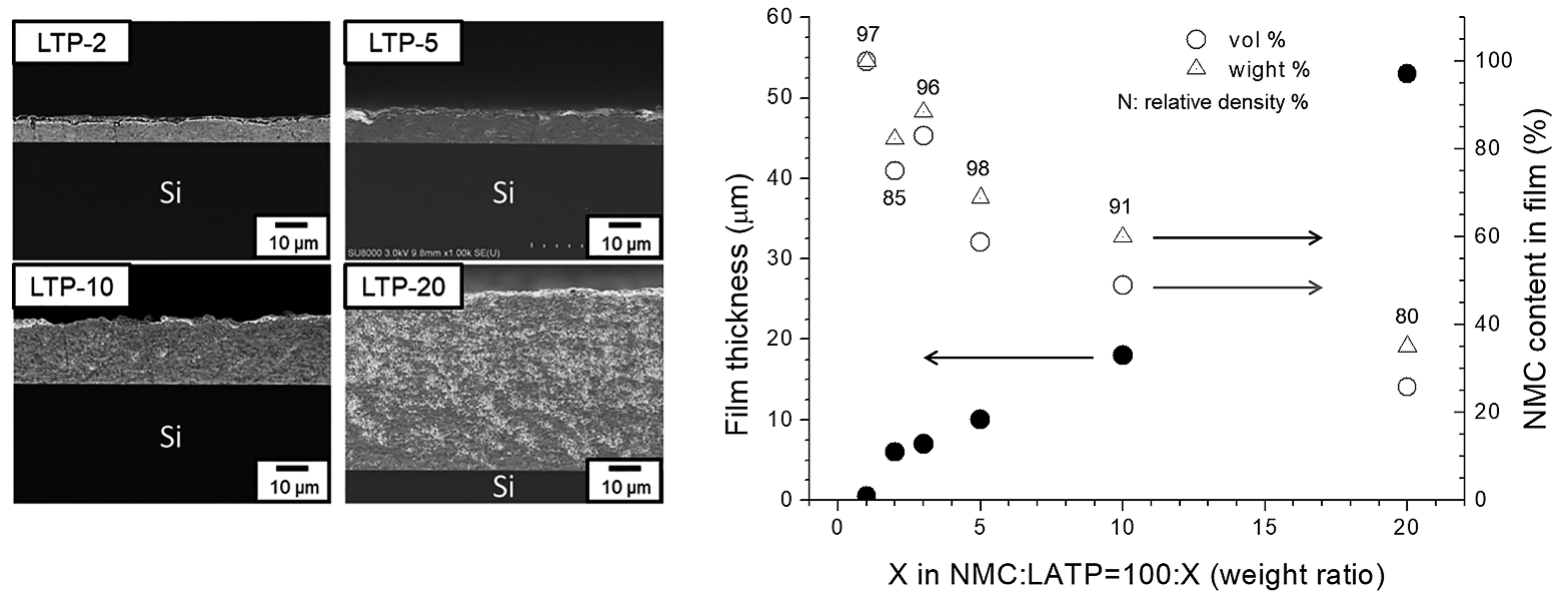

Fig. 8 (left) Cross-sectional SEM images of composite films using LTP-2,5,10, and 20. (right) Relationship between NCM amount in the composite electrode, density, and the film thickness. Numbers in Fig. 8 (right) means apparent density.
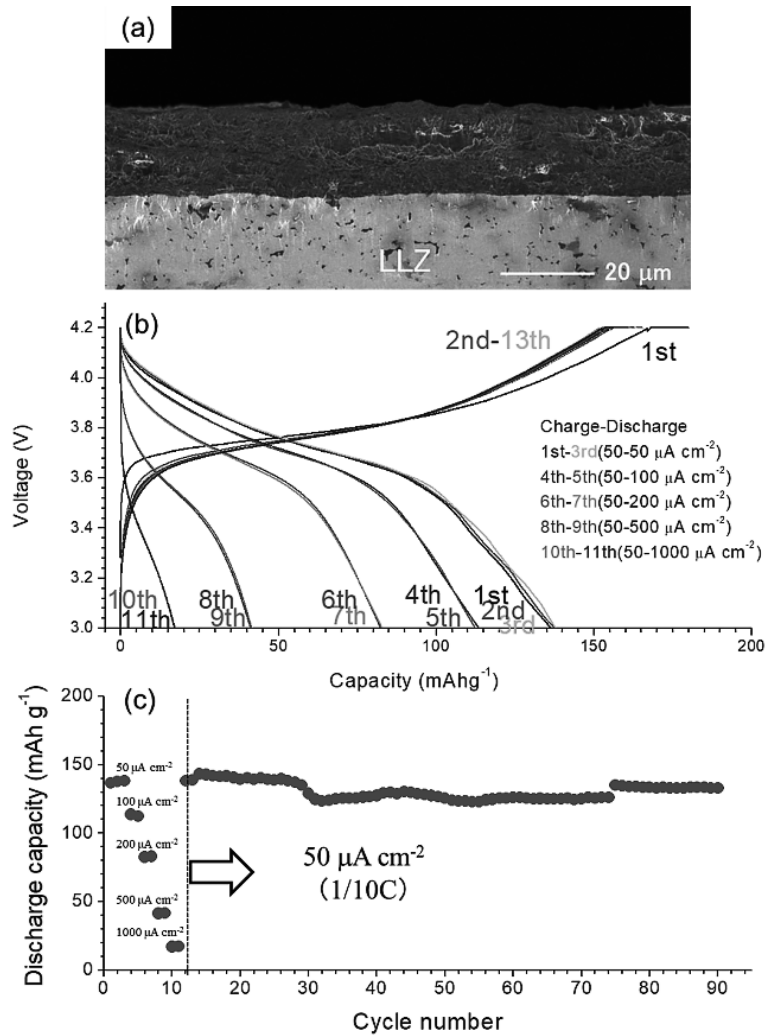

Fig. 9 (a) Cross-sectional SEM image of the composite electrode formed on LLZ substrate using LTP-5. (b) Charge-discharge curves of Li/ LLZ/NCM-LATP. (c) Cycle performance of Li/LLZ/NCM-LATP.

質であるため，複合電極を成膜した反対側に Li 金属を蒸着 することで，Li/LLZ/NCM-LATP の酸化物全固体リチウム電

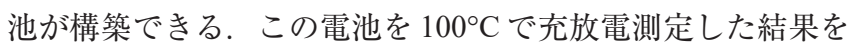
Fig. 9 (b) に示す. 充電電流は $50 \mu \mathrm{A} / \mathrm{cm}^{2}$ で一定とし, 放電電 流を 50-1000 $\mu \mathrm{A} / \mathrm{cm}^{2}$ に変えて放電容量の変化を調べた，その 結果, $1000 \mu \mathrm{A} / \mathrm{cm}^{2}$ の電流密度においても放電容量が観測さ れる程度の酸化物全固体リチウム電池が構築されることがわ かった．この測定の後, 放電電流値を $50 \mu \mathrm{A} / \mathrm{cm}^{2}$ に固定して 放電容量のサイクル依存性を測定した結果を Fig. 9 (c) に示

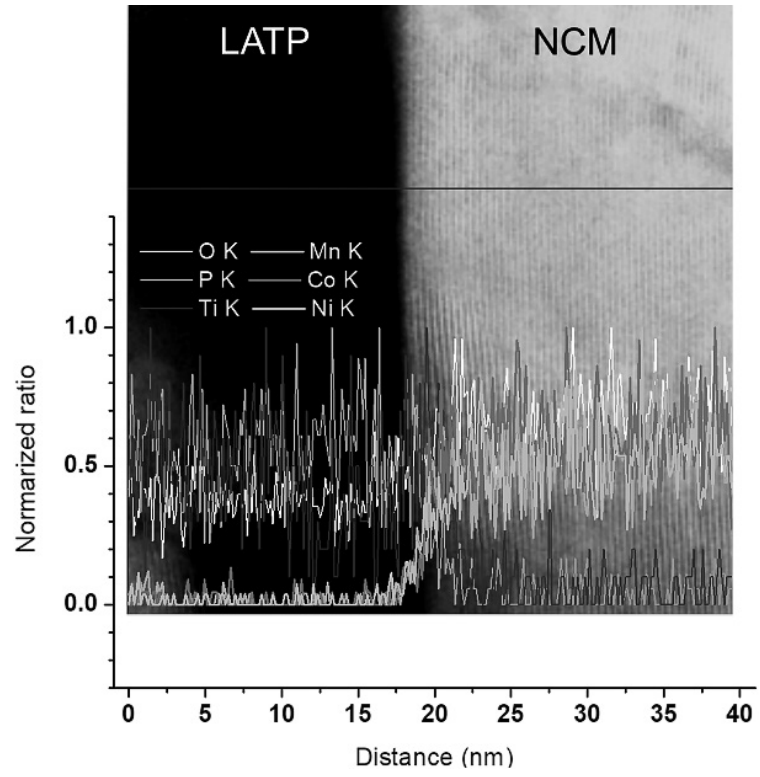

Fig. 10 Cross sectional EDX line profile around NCM-LATP interface in the composite electrode.

す．充放電反応を繰り返しても安定した放電容量が観測され ている様子がわかる，なお，この電池を $100^{\circ} \mathrm{C}$ で充放電させ ている一つの理由は Li/LLZ 界面での反応の安定性を確保す るためであるが, この詳細は文献を参照頂きたい ${ }^{10)}$.

Fig. 10 に複合膜内部の NCM-LATP 界面近傍の EDX 像を示 す. NCM と LATP の相互拡散層の厚みは $5 \mathrm{~nm}$ 程度と薄いこ とがわかる．この二つの材料は $500^{\circ} \mathrm{C}$ 程度で反応するため, 両者を緻密化するためにはそれ未満の温度で緻密な焼結体を 構築しなければならないが，一般的な混合・加圧の後に燒成

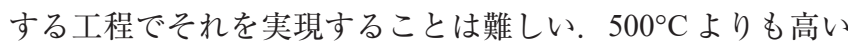
温度で焼結しょうとすると，界面にLiを含まない不純相が 形成され，これが $\mathrm{Li}^{+}$の移動を阻害して高抵抗界面が構築さ れる ${ }^{11)}$ このように, 高温では反応してしまう異種セラミッ クス材料を低温接合し，その複合材料の膜を高速に構築でき るのは $\mathrm{AD}$ 法の興味深い点である. 

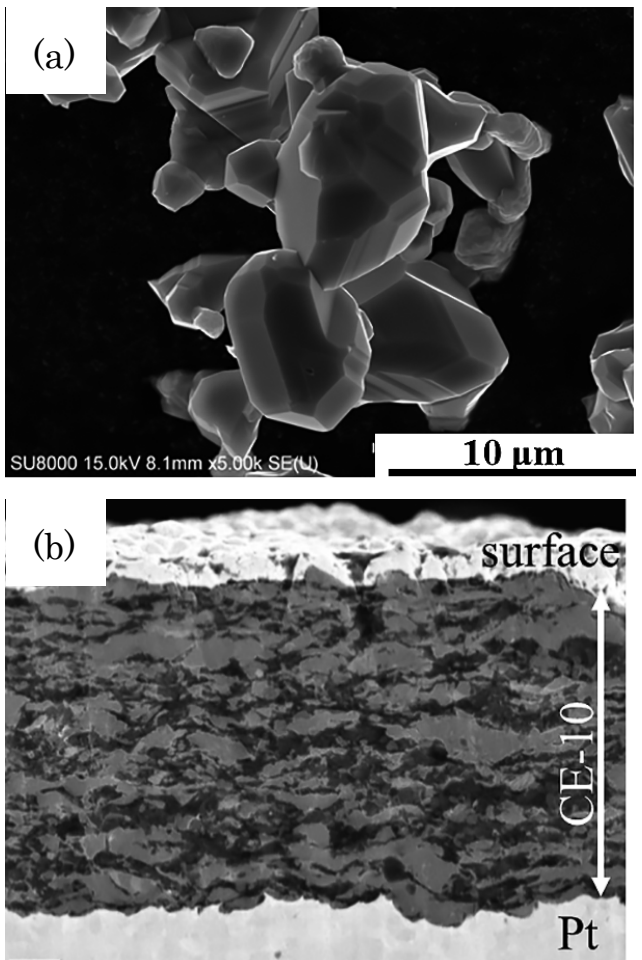

Fig. 11 (a) SEM image of LNM particle. (b) Cross-sectional SEM image of LNM-LATP composite film prepared on Pt substrate.

$4.25 \mathrm{~V}$ 級酸化物全固体リチウム電池の開発 ${ }^{12)}$

4.1 と同様な手法を用いることで，5V 級の酸化物全固体 リチウム電池の構築も可能である。ここでは, 電極活物質に スピネル型構造を有する $\mathrm{LiNi}_{0.5} \mathrm{Mn}_{1.5} \mathrm{O}_{4}$ （LNM）を用いた事 例について述べる.

Fig. 11 (a)に成膜に用いたLNM 粒子のSEM像を示す. Fig. 7 に示したNCM と平均粒径は同じ $(\sim 10 \mu \mathrm{m})$ である が，粒子表面にファセットが認められ，一次粒子径が大きな 粒子である. 4.1 と同様に，LNM 上にLATPを分散して Pt 基 板上に LNM-LATP 複合膜を構築すると，Fig. 11 (b) に示すよ うな複合膜が形成される。ここで，Pt 基板の表面形状をみ ると，大きく波打っている様子がわかる，これは， $\mathrm{AD}$ 成膜 時に生じた基板の変形である，成膜に用いる平均粒子径が同 じであっても，基板に与えられるエネルギーは粒子の結晶性 や構造などに依存することが推察される。実際, LNM-LATP 複合粒子を用いて LLZ 基板上に同条件で成膜すると基板が 破砕され，成膜が行えなかった。

Fig. 11 (b) に示した複合膜のXRD 測定を行うと，LNMに 帰属される回折ピークがシフトしており, 半值幅も増大して いた。これは，LNMを用いた複合膜において顕著に観測さ れる事例であり, $\mathrm{AD}$ 成膜過程で構造に大きな歪みが生じ, 結晶性も低下していると考えられる。これらの影響を回復 するために熱処理を検討した．複合膜を構築した後に 400 , $500,600,700^{\circ} \mathrm{C}$ で熱処理し，得られた複合膜の上に固体電 解質, $\mathrm{Li}$ 金属を成膜して全固体電池を構築し, その放電曲 線を比較した結果を Fig. 12 (a)に示す.また，その微分曲線 を Fig. 12 (b) に示す. $500^{\circ} \mathrm{C}$ の熱処理で放電曲線の電位平坦 (a)

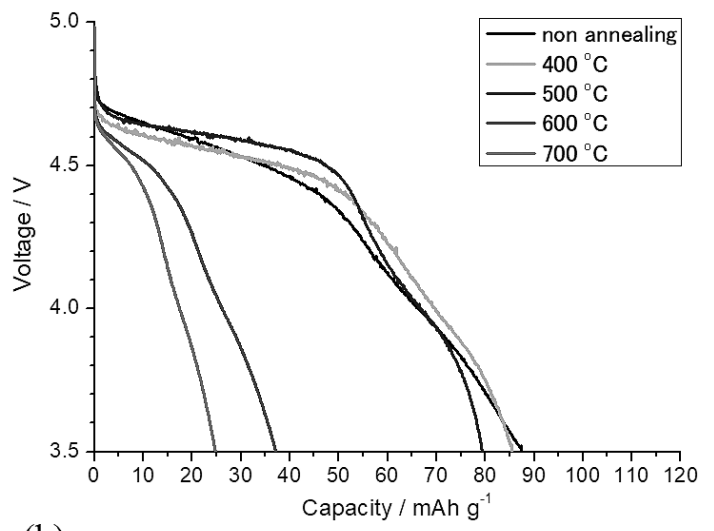

(b)

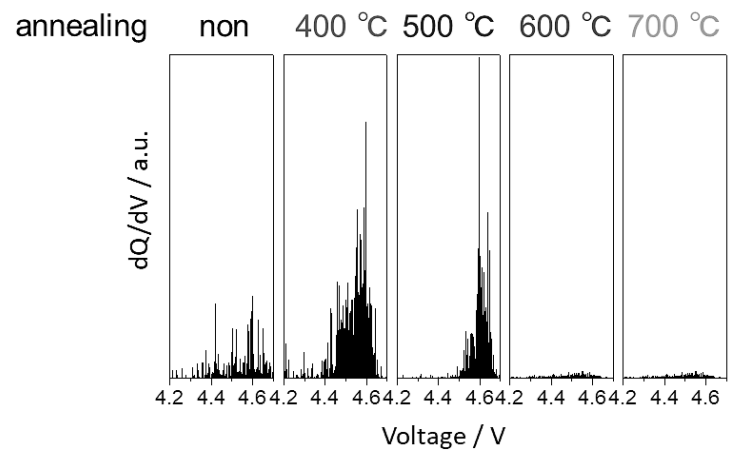

Fig. 12 (a) Charge-discharge curves of all-solid-state batteries, where the LNM-LATP composite films were annealed at different temperature. (b) Differential curves of discharge curves.

部が明確に現れるようになり，この様子は微分曲線で $4.6 \mathrm{~V}$ あたりにシャープなピークとして現れている，一方，熱処理 温度を $600^{\circ} \mathrm{C}$ 以上にすると放電容量が大幅に減少することが Fig. 12 (a)からわかる.これは, LNM と LATPが $600^{\circ} \mathrm{C}$ 以上 の温度で酸素放出を伴う副反応を起こすことで界面抵抗が増 大することに起因すると考えられる.

このように， $\mathrm{AD}$ 法を用いて $5 \mathrm{~V}$ 級正極と固体電解質を複 合体を構築し，それを活用した酸化物全固体リチウム電池の 作製も可能であるが，LNMを用いた酸化物全固体リチウム 電池の充放電反応の安定性はNCM-LATP 複合体を用いた電 池よりも低い. その一つの要因は, $\mathrm{Li}^{+}$の挿入脱離反応に伴っ て LNM が 6\% 程度の体積変化をするためと考えられる. 実 際, 充放電反応後の複合膜内部にはクラックが多数形成され ており, クラック形成により複合膜の抵抗が増大（或いは失 活領域の形成）に起因すると考えられる。

4.3 逆積層型酸化物薄膜電池の開発 ${ }^{13)}$

緒言で述べたように，IoT用の電源として酸化物系の薄膜 型全固体電池が期待されている。薄膜型全固体電池は一般に 基板上に LCO 等の正極膜を作製し，その後 LiPON 等のガラ ス電解質, $\mathrm{Li}$ 金属をそれぞれ RF スパッタリング, 真空蒸着 法などを用いて順次積層して構築される。この $\mathrm{Li}$ 金属は正 極を充電する過程で電析により形成することが可能である. 電析 $\mathrm{Li}$ を有効に活用できれば $\mathrm{Li}$ 金属の蒸着が不要となり, 電池作製プロセスを簡略化できる. 
(a)

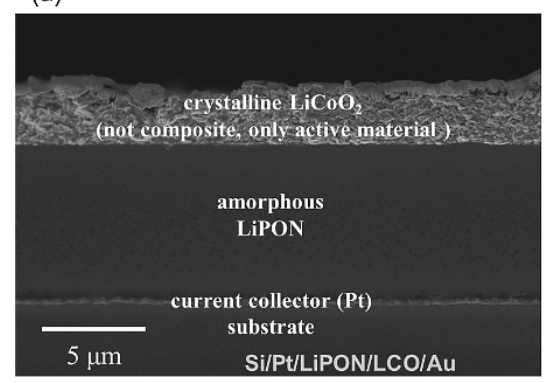

(b)

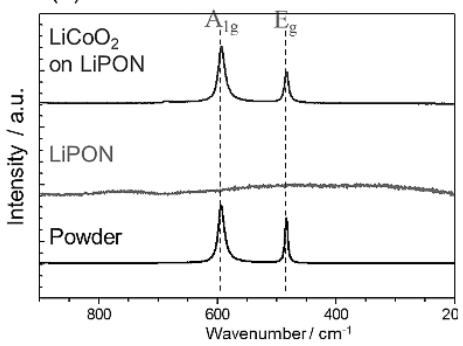

(c)

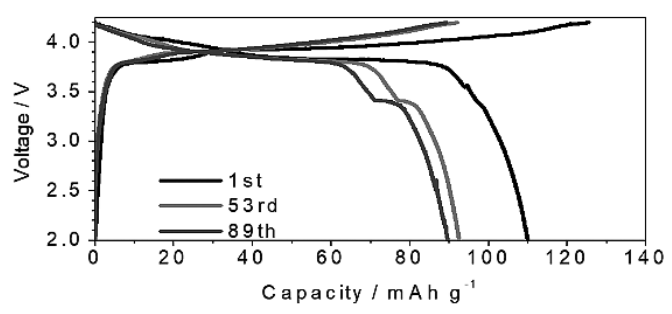

Fig. 13 (a) Cross-sectional SEM image of LCO film prepared by AD on Si/Ti/Pt/LiPON substrate. (b) Raman spectra of LCO mother powder, LiPON, and LCO film. (c) Charge-discharge curves of SUS/Pt/LiPON/AD-LCO/ Au battery. $I=5 \mu \mathrm{A} / \mathrm{cm}^{2}$.

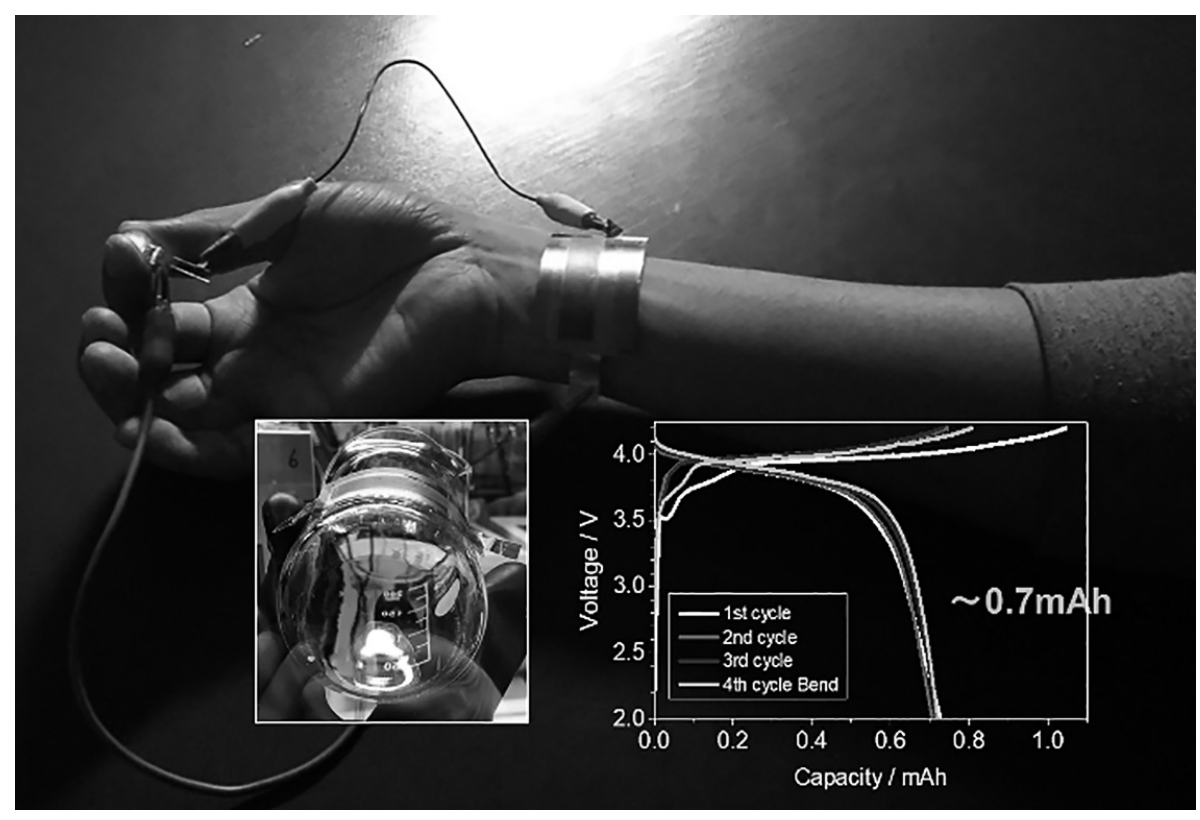

Fig. 14 Flexible all-solid-state battery prepared only by room temperature process, where electrochemical grown Li is used in the battery.

電析 Li は極めて活性であるため, 副反応を抑制するには シール材が必要となるが, 固体電解質である LiPONが良好 なシール材として機能する ${ }^{14)}$. 従って, 集電体 $/ \mathrm{LiPON} /$ 正 極の積層体を構築できれば，電析 Li は集電体／LiPON の間 に閉じ込められ，固体電解質自身がシール材となることで安 定した充放電反応の実現が期待できる，一方，多くの正極は 結晶性材料であり, その結晶化には $500^{\circ} \mathrm{C}$ 以上の温度が必要 である。これに対し, LiPON は $250^{\circ} \mathrm{C}$ 以上に加熱されると 結晶化してイオン伝導率が低下する.

上記のような熱安定性のミスマッチを解消して集電体／ $\mathrm{LiPON} /$ 正極の逆積層型薄膜電池を構築する上で, $\mathrm{AD}$ 法が 活用できる. Fig. 13 (a) は集電体 $/$ LiPONの上に AD 法を用 いて LCO 薄膜を常温成膜した試料の断面 SEM 像である. $\mathrm{LiPON}$ は $10 \mu \mathrm{m}$ 程度の薄膜であるため, 本事例では共沈法 で作製した $2 \mu \mathrm{m}$ 程度の自作の LCO 粒子を用いた ${ }^{15)}$. Fig. 13 (b) に示すラマンスペクトルから作製したLCO膜は出発粒子 と同じ層状岩塩型構造を有することがわかる．また，作製し た積層体は Fig. 13 (c) に示すように $4 \mathrm{~V} て ゙$ 充放電する薄膜型 電池となる。このような知見を活用すると，例えば Fig. 14
に示すような電析 Li を活用するフレキシブル薄膜型全固体 電池を全常温プロセスにより構築することも可能となる.

\section{5 おわりに}

酸化物全固体リチウム電池の開発において, 低抵抗な電極 - 固体電解質の複合体を構築することは電池の高性能化に重 要な課題の一つである. 低抵抗界面を構築するための一つの 指針は, 電極と固体電解質を緻密で, 且つできるだけ薄い相 互拡散層を備えた状態で接合することである，そのような複 合体を膜として構築する手法の一つとして，電極－固体電 解質の複合粒子を用いた $\mathrm{AD}$ 法が有効な手法である。その際 に, 複合粒子の混合方法, 表面物性, 母粒子の形状が複合膜 に及ぼす影響についてもあわせて述べた，本報で紹介した酸 化物全固体リチウム電池は $1 \mathrm{~cm}$ 角のサイズではあるが，大 型の $\mathrm{AD}$ 装置を用いれば例えば $10 \mathrm{~cm}$ 角サイズの成膜も可能 となる.

このように, $\mathrm{AD}$ 法は酸化物全固体リチウム電池の開発に おいて有用な手法の一つではあるが, 実用化においては原料 が膜化される際の歩留まりを向上するなど, 課題も多い. 
$\mathrm{AD}$ の成膜原理の基礎的な面，特に表面活性化による接合と その制御手法があきらかにされ，酸化物全固体リチウム電池 を構築する実用的な手法として発展していくことを期待した い，その際，原料となる粉体材料設計は大きな鍵になると考 えられる。

\section{6 謝辞}

本研究は JST ALCA-SPRING（JPMJAL1301）及び 一部を KRI, NEDO, 科研費新学術領域 (JP19H05813 \& JP19H05815) “蓄電固体界面科学” の援助をうけて行いました，関倸各位 に厚く御礼申し上げます。

\section{文献}

1) Please refer to the following home pages of Japanese national projects on next-generation battery.

JST ALCA-SPRING: https://www.jst.go.jp/alca/alca-spring/ project/ (accessed Dec.25, 2019)

NEDO RISING2: http://www.rising.saci.kyoto-u.ac.jp/ (accessed Dec.25, 2019)

NEDO SOLiD-EV: https://www.nedo.go.jp/activities/ ZZJP_100146.html (accessed Dec.25, 2019)

2) B. Wang, J. B. Bates, F. X. Hart, B. C. Sales, R. A. Zuhr, J. D. Robertson: J. Electrochem. Soc., 143 (1996) 3203-3213.

3) J. B. Bates, N. J. Dudney, B. Neudecker, A. Ueda, C. D. Evans: Solid State Ionics, 135 (2000) 33-45.

4) J. Akedo (Ed): Progress of Aerosol Deposition Method Utilization Front of Room Temperature Impact Consolidation Phenomenon-, CMC (2019).
5) J. Akedo: J. Am. Ceram. Soc., 89 (2006) 1834-1839.

6) E. Fuchita, E. Tokizaki, Y. Sakka: J. Ceramic. Soc. Japan., 118 (2010) 767-770.

7) E. Fuchita, E. Tokizaki, E. Ozawa: J. Jpn. Soc. Powder Metallurgy, 63 (2016) 937-946.

8) S. Iwasaki, T. Hamanaka, T. Yamakawa, W. C. West, K. Yamamoto, M. Motoyama, T. Hirayama, Y. Iriyama: J. Power Sources, 272 (2014) 1086-1090.

9) T. Kato, S. Iwasaki, Y. Ishii, M. Motoyama, W. C. West, Y. Yamamoto, Y. Iriyama: J. Power Sources, 303 (2016) 65-72.

10) F. Yonemoto, A. Nishimura, M. Motoyama, N. Tsuchimine, S. Kobayashi, Y. Iriyama: J. Power Sources, 343 (2017) $207-$ 215.

11) T. Kato, R. Yoshida, K. Yamamoto, T. Hirayama, M. Motoyama, W. C. West, Y. Iriyama: J. Power Sources, 325 (2016) 584-590.

12) Y. Iriyama, M. Wadaguchi, K. Yoshida, Y. Yamamoto, M. Motoyama, T. Yamamoto: J. Power Sources, 385 (2018) 5561.

13) T. Yamamoto, H. Iwasaki, Y. Suzuki, M. Sakakura, Y. Fujii, M. Motoyama, Y. Iriyama: Electrochem. Comm., 105 (2019) UNSP 106494.

14) B. J. Neudecker, N. J. Dudney, J. B. Bates: J. Electrochem. Soc., 147 (2000) 517-523.

15) M. Motoyama, S. Iwasaki, M. Sakakura, Y. Iriyama: Int. J. Mat. Res. (2019) accepted. 